\title{
Synthesis of Optically Active 1,3,2-Oxazaphospholidine 2-Sulfides and 1,3,2-Benzodioxaphosphorin 2-Sulfides
}

\author{
Shao-Yong Wu, Akinori Hirashima, Eiichi Kuwano \\ and Morifusa Eтo \\ Department of Agricultural Chemistry, Kyushu University, \\ Fukuoka 812, Japan
}

Received September 12, 1986

\begin{abstract}
The optical isomers of ten kinds of insecticidal 1,3,2-oxazaphospholidine 2-sulfides (OS) and two kinds of 1,3,2-benzodioxaphosphorin 2-sulfides (BS), including the commercial insecticide salithion, were synthesized in high optical purity by using two optically active aryl methyl phosphorochloridothionates (AMPC) as chiral two-step phosphorylating reagents. Their configurations were assigned according to the reaction mechanisms and supported by proton NMR information.
\end{abstract}

Some 1,3,2-oxazaphospholidine 2-sulfides (OS) and 1,3,2-benzodioxaphosphorin 2-sulfides (BS) show potent insecticidal activities, ${ }^{1)}$ 2-methoxy-4H-1,3,2-benzodioxaphosphorin 2sulfide (salithion) having been used as an effective, broad-spectrum agricultural insecticide for many years. ${ }^{2)}$ Although many different organophosphorus compounds are important pesticides in use, few have a cyclic structure with phosphorus as a ring member.

Both insecticidal OS and BS have an asymmetric phosphorus and, in most cases, also an asymmetric carbon in the molecule: therefore, two or four optical isomers exist. In order to study the relationship between the insecticidal activity and absolute configuration of these compounds, syntheses of their optical isomers were carried out by using two optically active aryl methyl phosphorochloridothionates (AMPC), that is, 2,6-dichloro-4-methylphenyl methyl phosphorochloridothionate (CMPC) and methyl 4-nitrophenyl phosphorochloridothionate (MNPC). ${ }^{3)}$ These were prepared in an optically pure state and are useful as chiral two-step phosphorylating reagents. This paper deals with the syntheses of optically active OS
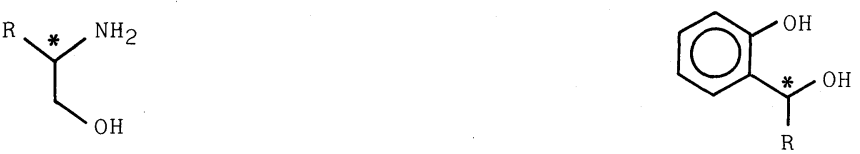

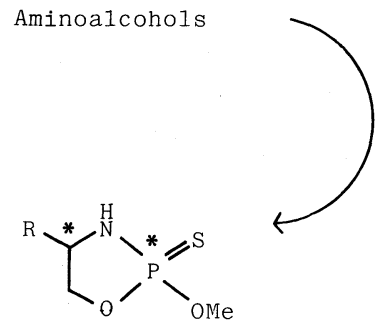

Oxazaphospholidines

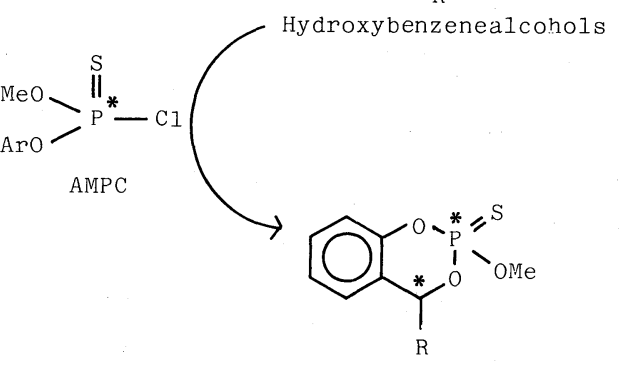

Benzodioxaphosphorins

SCHEME 1. Syntheses of Optically Active Oxazaphospholidines and Benzodioxaphosphorins Using AMPC Chiral Two-step Phosphorylating Agents. 
and BS. Their insecticidal activities against several kinds of insects will be reported elsewhere.

\section{Synthesis}

The reaction shown in Scheme 1 was found to be useful for the synthesis of optically active OS and BS. All of the stereoisomers in Tables I and II were synthesized according to this scheme.

The optically active aminoalcohols used were either commercial reagents or were synthesized from the corresponding amino acids. 2-Hydroxybenzenemethanol (saligenin) was a purchased reagent, and 2-(1-hydroxyethyl)-4chlorophenol was prepared from 4-chlorophenol through successive acetylation, Fries rearrangement and reduction. Because this prepared reagent was a racemic mixture, the diastereomeric mixtures of BS derived from it were separated by column chromatography.

The enantiomers of CMPC and MNPC used for these syntheses were all nearly optically pure, based on the ${ }^{1} \mathrm{H}$-NMR spectra of their $(S)$-phenylethylamine derivatives. Details concerning their configuration and preparations have been described in our previous paper. ${ }^{3)}$

Tables I and II show all of the optically active OS and BS that were synthesized. Their chemical structures were confirmed by mass, ${ }^{1} \mathrm{H}$ - and ${ }^{31} \mathrm{P}-\mathrm{NMR}$ spectrometric analysis.

\section{Reaction mechanism and absolute configuration}

The reactions of 2-aminoalcohols with CMPC or MNPC have been deeply investigated and the mechanism proposed as two successive nucleophilic substitutions; that is, the amino group displaces the chloride ion first, and the amide formed then undergoes intramolecular cyclization by the attack of the hydroxyl group to leave the aryloxide ion, both of the nucleophilic substitutions occurring at phosphorus and proceeding with inversion (Scheme 2). ${ }^{3)}$ Such a mechanism is also consistent with the assignment of cis and trans relationships between the ring substituents and the $\mathrm{P}=\mathrm{S}$ bond in the optical isomers of OS that are produced, as will be discussed later.
Table I. Yield and Optical Rotation of Optically ACtive 4-(OR 5-) Substituted-2METHOXY-1,3,2-OXAZAPHOSPHOLIDINE 2-SULFIDES (OS)

\begin{tabular}{|c|c|c|c|c|}
\hline \multirow{2}{*}{$\mathbf{R}$} & \multicolumn{2}{|c|}{ Configuration } & \multirow{2}{*}{$\begin{array}{l}\text { Yield } \\
(\%)\end{array}$} & \multirow{2}{*}[\alpha]{$_{\mathrm{D}}^{\circ}\left(c, \mathrm{CHCl}_{3}\right)$} \\
\hline & $\mathrm{C}$ & $\mathrm{P}$ & & \\
\hline $\mathrm{H}$ & & $R$ & 75 & $+6.3(0.41)$ \\
\hline $\mathrm{H}$ & & $S$ & 68 & $-6.2(0.48)$ \\
\hline 4-Me & $S$ & $R$ & 53 & $+24.1(0.29)$ \\
\hline 4-Me & $R$ & $S$ & 47 & $-21.9(0.32)$ \\
\hline 4-Me & $S$ & $S$ & 45 & $-6.7(0.44)$ \\
\hline 4-Me & $R$ & $R$ & 58 & $+7.4(0.27)$ \\
\hline 4-Et & $S$ & $R$ & 56 & $+16.8(2.56)$ \\
\hline 4-Et & $R$ & $S$ & 61 & $-15.3(1.78)$ \\
\hline 4-Et & $S$ & $S$ & 52 & $-22.2(4.50)$ \\
\hline 4-Et & $R$ & $R$ & 43 & $+21.3(3.92)$ \\
\hline 4- ${ }^{\mathrm{i}} \mathrm{Pr}$ & $S$ & $R$ & 56 & $+7.1(0.49)$ \\
\hline 4- $\mathrm{Pr}$ & $R$ & $S$ & 61 & $-7.1(0.85)$ \\
\hline $4-^{1} \mathrm{Pr}$ & $S$ & $S$ & 47 & $-27.9(0.20)$ \\
\hline 4- ${ }^{\mathrm{i}} \mathrm{Pr}$ & $R$ & $R$ & 55 & $+25.5(0.22)$ \\
\hline 4-' ${ }^{\mathrm{B} u}$ & $S$ & $R$ & 15 & $+9.4(0.14)$ \\
\hline $4-^{t} \mathrm{Bu}$ & $R$ & $S$ & 15 & $-9.0(0.10)$ \\
\hline $4-{ }^{t} \mathrm{Bu}$ & $S$ & $S$ & 29 & $-30.0(0.15)$ \\
\hline 4-'Bu & $R$ & $R$ & 21 & $+29.2(0.15)$ \\
\hline $4-^{\mathrm{i}} \mathrm{Bu}$ & $S$ & $R$ & 64 & $+5.0(0.80)$ \\
\hline $4-^{\mathrm{i}} \mathrm{Bu}$ & $R$ & $S$ & 56 & $-4.7(0.75)$ \\
\hline $4-{ }^{i} \mathrm{Bu}$ & $S$ & $S$ & 72 & $-15.0(1.00)$ \\
\hline $4-^{\mathrm{i}} \mathrm{Bu}$ & $R$ & $R$ & 55 & $+15.1(0.76)$ \\
\hline 4- ${ }^{\mathrm{s}} \mathrm{Bu}$ & $S$ & $R$ & 64 & $+9.3(1.62)$ \\
\hline $4-{ }^{\mathrm{s}} \mathrm{Bu}$ & $S$ & $S$ & 69 & $-11.5(3.13)$ \\
\hline $4-\mathrm{Ph}$ & $S$ & $R$ & 44 & $+57.2(1.68)$ \\
\hline 4-Ph & $R$ & $S$ & 22 & $-57.2(1.52)$ \\
\hline 4-Ph & $S$ & $S$ & 38 & $+56.2(1.57)$ \\
\hline 4-Ph & $R$ & $R$ & 29 & $-55.6 .(2.54)$ \\
\hline $4-\mathrm{Bz}$ & $S$ & $R$ & 59 & $-80.8(0.63)$ \\
\hline $4-\mathrm{Bz}$ & $R$ & $S$ & 72 & $+81.4(0.70)$ \\
\hline $4-\mathrm{Bz}$ & $S$ & $S$ & 55 & $-73.3(0.72)$ \\
\hline $4-B z$ & $R$ & $R$ & 64 & $+73.6(0.68)$ \\
\hline $5-\mathrm{Me}$ & $S$ & $R$ & 19 & \\
\hline $5-\mathrm{Me}$ & $R$ & $S$ & 42 & \\
\hline 5-Me & $S$ & $S$ & 41 & \\
\hline 5-Me & $R$ & $R$ & 35 & \\
\hline $5-\mathrm{Et}$ & $R S$ & $R S$ & 38 & \\
\hline
\end{tabular}

Table II. Spectral Data of Optically Active 1,3,2-BENZODIOXAPHOSPHORIN 2-SULFIDES (BS)

\begin{tabular}{lccc}
\hline $\begin{array}{c}\text { Compound \& } \\
\text { configuration }\end{array}$ & $\begin{array}{c}{ }^{31} \mathrm{P}-\mathrm{NMR} \\
(\delta \mathrm{ppm})\end{array}$ & $e . e . \%$ & $\begin{array}{c}{[\alpha]_{\mathrm{D}}} \\
{ }^{\circ}(c / \mathrm{MeCN})\end{array}$ \\
\hline$(S)$-Salithion & 59.9 & 84 & $-7.8(0.32)$ \\
$(R)-$ Salithion & 59.9 & 79 & $+7.0(0.40)$ \\
$(R)_{\mathrm{C}}(S)_{\mathrm{P}}$-CMMBS & 60.6 & & $+19.4(0.57)$ \\
$(S)_{\mathrm{C}}(R)_{\mathrm{P}}-\mathrm{CMMBS}$ & 60.6 & & $-19.2(0.26)$ \\
$(S)_{\mathrm{C}}(S)_{\mathrm{P}}-\mathrm{CMMBS}$ & 58.9 & 97 & $-25.0(0.48)$ \\
$(R)_{\mathrm{C}}(R)_{\mathrm{P}}-\mathrm{CMMBS}$ & 58.9 & 97 & $+24.6(0.41)$ \\
\hline
\end{tabular}




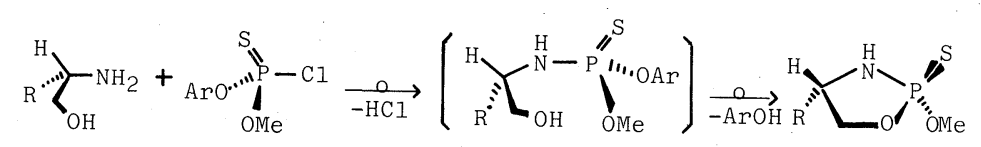

SCHEME 2. Proposed Mechanism for Oxazaphospholidines Synthesis with AMPC.

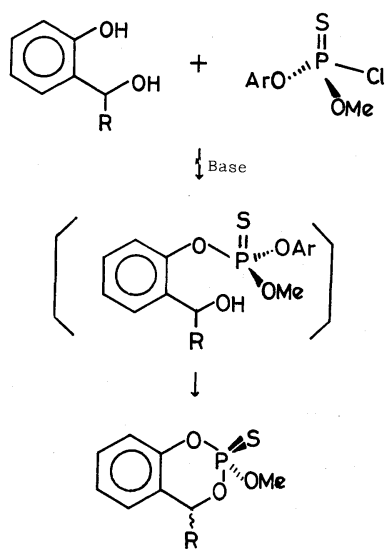

SCHEmE 3. Proposed Mechanism for Benzodioxaphosphorins Synthesis with AMPC.

The reactions deriving the optical isomers of BS were deduced to occur by a mechanism similar to that described above: instead of by the amino group, the reaction was initiated by the attack of the phenolic hydroxyl group to displace the chloride ion, followed by substitution of the alkoxide for the aryloxide, the second leaving group of AMPC. Both steps took place at the same phosphorus with Walden inversions and finally gave the product either as an enantiomer or, when a racemic hydroxybenzenealcohol was used, as a diastereomeric mixture (Scheme 3).

This reaction mechanism is mainly based on the facts that an ionized phenolic hydroxyl group is more active to attack electropositive phosphorus than a neutral alcoholic one, ${ }^{4)}$ and that all available data on the stereochemistry of displacement of the chloride and aryloxide in acyclic organophosphorus compounds show that the reactions occur with inversion of the phosphorus configuration. ${ }^{5)}$

The absolute configuration of optically active OS was assigned according to those of the two-step phosphorylating reagents and aminoalcohols used for each preparation, and according to the reaction mechanism.

Among the diastereomers, the cis and trans relationships between the ring substituent and the $\mathrm{P}=\mathrm{S}$ bond can be determined according to their proton NMR spectra, because the protons in a cis relationship to the $\mathrm{P}=\mathrm{S}$ bond in such kinds of cyclic phosphorus compounds are deshielded. ${ }^{6 \sim 8)}$ For example, $(R)_{\mathrm{C}}(R)_{\mathrm{P}}-4$ isopropyl-2-methoxy-1,3,2-oxazaphospholidine 2-sulfide was derived from D-valinol and $(S)-(+)$-CMPC; the proton located at the 4-position in cis to the $\mathrm{P}=\mathrm{S}$ bond was apparently deshielded, shifting $0.16 \mathrm{ppm}$ to a lower field (Table III). The protons in the 4-alkyl substituents showed that the nearer to the $\mathrm{C}_{4}$ atom a proton was, the more obviously it was deshielded. In all of the products with a ring substituent, the deshielding effect was observed as expected. In the OS series, the $\mathrm{N}-\mathrm{H}$ protons of the cis and trans isomers also appeared at different chemical shifts. If it is presumed that the $\mathrm{N}-\mathrm{H}$ bond orients trans to the $\mathrm{C}_{4}$ substituent in a thermodynamically stable state due to steric interaction between them, the results shown in Table III can also be attributed to the $\mathrm{P}=\mathrm{S}$ deshielding effect. All this information in turn verified the proposed reaction mechanisms.

The configurations of $\mathrm{C}_{4}$ in 2-methoxy-4methyl-6-chloro-BS (CMMBS) were determined after chromatographic separations of the prepared diastereomeric mixture. The starting AMOS possessed the confirmed absolute configuration at phosphorus, which was transformed into that of CMMBS in the above-mentioned stereochemical way (Scheme 3 ), so that the absolute configuration of $\mathrm{C}_{4}$ in CMMBS could be determined by clarifying the relative relationship between the $\mathrm{C}_{4}$ methyl and the $\mathrm{P}=\mathrm{S}$ bond in each optical isomer. This was done on the basis of their ${ }^{1} \mathrm{H}-\mathrm{NMR}$ 
spectra by considering the deshielding effect of the $\mathrm{P}=\mathrm{S}$ bond to a cis proton in the ring structure.

Table IV gives a comparison between the NMR data of CMMBS and 2-ethoxy-4methyl-1,3,2-dioxaphosphorin 2-sulfides, the cis and trans configurations of the latter having been assigned on NMR and dipolemoment studies. ${ }^{9)}$ The chemical structure of these two kinds of compounds is similar, so that their cis and trans isomers would show

TABle III. ${ }^{1}$ H-NMR Chemical ShIFt COMPaRison BETWEEN THE cis AND trans ISOMERS OF ${ }^{\text {PPMOS }}$

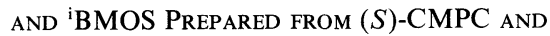
Corresponding Aminoalcohols

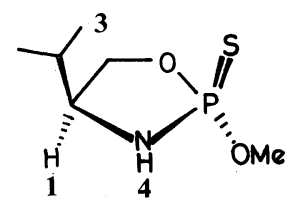

$(S)_{\mathrm{C}}(R)_{\mathrm{P}^{-}}{ }^{\mathrm{i}} \mathrm{PMOS}(c i s)$

\begin{tabular}{lcccc}
\hline \multirow{2}{*}{$\begin{array}{c}\text { Compound and } \\
\text { configuration }\end{array}$} & \multicolumn{4}{c}{${ }^{1} \mathrm{H}-\mathrm{NMR}(\delta \mathrm{ppm})$} \\
\cline { 2 - 6 } & $\mathbf{1}$ & $\mathbf{2}$ & $\mathbf{3}$ & $\mathbf{4}$ \\
\hline$(S)_{\mathrm{C}}(R)_{\mathrm{P}}{ }^{-} \mathrm{PMOS}($ cis $)$ & 3.36 & 1.72 & 0.96 & 3.20 \\
$(R)_{\mathrm{C}}(R)_{\mathrm{P}}-\mathrm{PMOS}($ trans $)$ & 3.52 & 1.60 & 0.94 & 3.28 \\
$(S)_{\mathrm{C}}(R)_{\mathrm{P}}-{ }^{-} \mathrm{BMOS}($ cis $)$ & 3.80 & 1.52 & 0.96 & 3.04 \\
$(R)_{\mathrm{C}}(R)_{\mathrm{P}}{ }^{-} \mathrm{BMOS}($ trans $)$ & 3.88 & 1.40 & 0.94 & 3.24 \\
\hline
\end{tabular}

corresponding features in NMR spectra. The data in Table IV verify this deduction.

Other evidence supporting the assignment of the cis and trans configurations came from ${ }^{31} \mathrm{P}$ NMR monitoring of the oxidative desulfurization of OS and BS by $m$-chloroperbenzoic acid (MCPBA). Owing to the steric hindrance of a cyclic substituent, the $\mathrm{P}=\mathrm{S}$ bond in the $c i s$ isomers of OS as well as BS was oxidized more slowly than that in the trans isomers (Fig. 1).

\section{Optical purity}

The reactions in Scheme 1 proceeded with high functional selectivity and stereospecificity, the optical purity of OS mainly depending on that of the AMPC used. Figure 2 is the ${ }^{31} \mathrm{P}-\mathrm{NMR}$ monitoring of three preparations of 4-isobutyl OS ('BMOS) using CMPC of differing optical purity. It is very convenient and reliable to use ${ }^{31} \mathrm{P}-\mathrm{NMR}$ for determining the optical purity of OS produced, because two sharp peaks of the cis and trans isomers of OS could be observed at obviously different chemical shifts, provided that racemic AMPC was used or that some epimerization occurred, even if optically pure enantiomers of both AMPC and aminoalcohols were used. In fact, such epimerization was not detected in any of the syntheses shown in Table I using optically pure aminoalcohols and AMPC, this being

TABle IV. ${ }^{1} \mathrm{H}-$ AND ${ }^{31} \mathrm{P}-\mathrm{NMR}$ Features of cis and trans Dioxaphosphorin 2-Sulfides

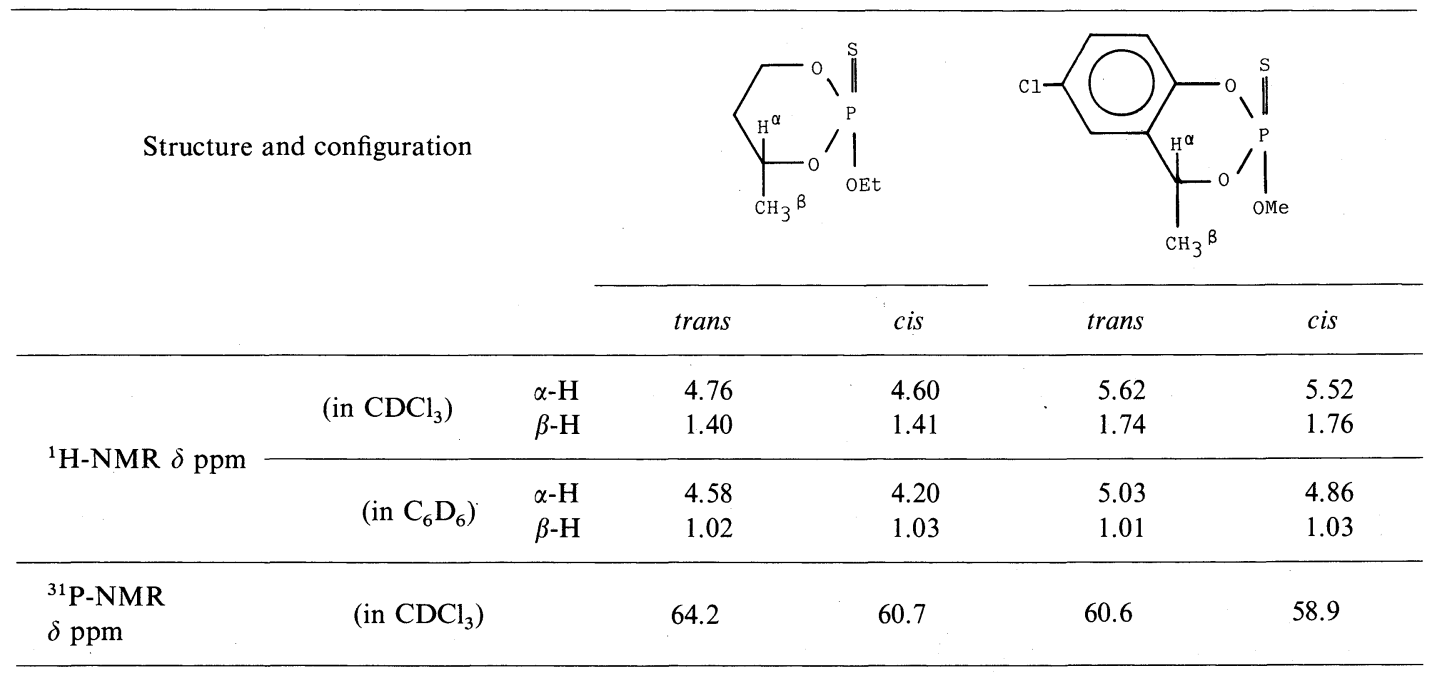




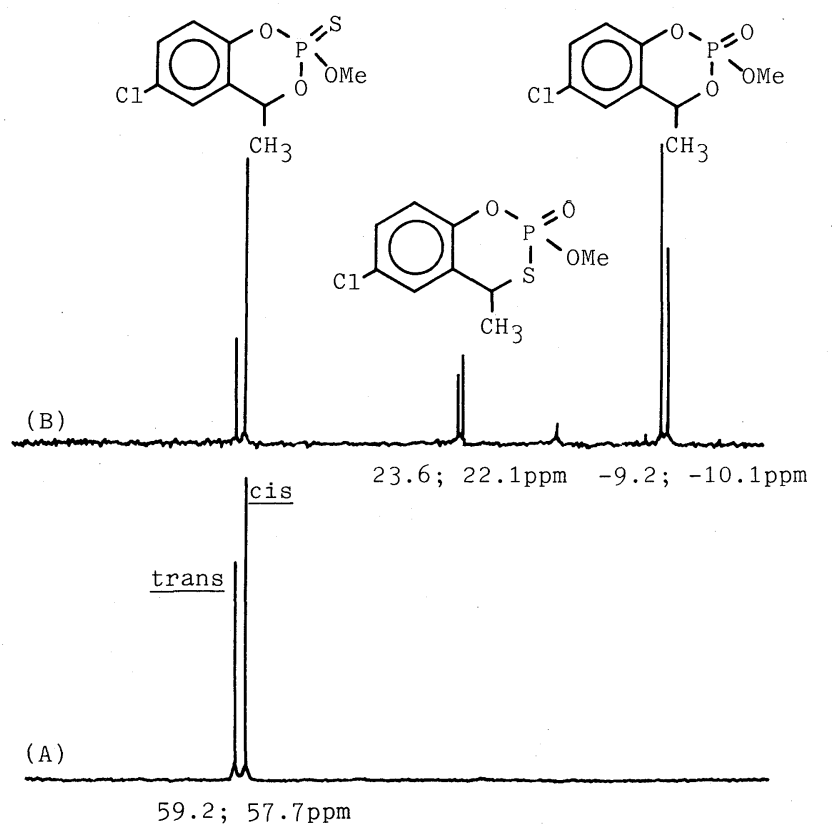

FIG. 1. ${ }^{31}$ P-NMR Monitoring of the Reaction between CMMBS and MCPBA in THF.

(A) cis and trans CMMBS; (B)+ MCPBA for $5 \mathrm{~min}$. The identification of the products was described in our previous paper submitted to J. Pesticide Sci., 1986.

demonstrated in Fig. 3, where a signal at $61 \mathrm{ppm}$ was due to CMPC and those at 87 and $88 \mathrm{ppm}$ were due to the cis and the trans isomers of ${ }^{\mathrm{i}} \mathrm{BMOS}$, respectively.

Therefore, all the stereoisomers of OS listed in Table I were considered to be almost optically pure. Their ${ }^{31} \mathrm{P}-\mathrm{NMR}$ spectra recorded after being bioassayed and kept below $5^{\circ} \mathrm{C}$ for three months indicated no occurrence of epimerization to any extent.

An HPLC analysis using a chiral CHIRALPAK OT $(+)$ column was found to be effective for separating the enantiomers of salithion and cis CMMBS. Methanol was the most suitable eluant. Under the conditions mentioned in the experimental section, the retention times were nearly 4.7 and $5.6 \mathrm{~min}$ (Fig. 4) for $(S)-(-)$ - and $(R)-(+)$-salithion, respectively; and were 8.6 and $9.4 \mathrm{~min}$, for $(S)_{\mathrm{C}}(S)_{\mathrm{P}^{-}}(-)$- and $(R)_{\mathrm{C}}(R)_{\mathrm{P}^{-}}-(+)$-cis CMMBS, respectively.

The optical purity of salithion was affected greatly by the reaction conditions. When prepared in an aqueous sodium hydroxide so- lution, two enantiomers were produced in an almost 1:1 ratio. This was thought to be the result of some exchange of the displaced chloride ions and the aryloxide of AMPC, which caused racemization of the AMPC during the reaction, because the aqueous solution could increase the reactivity of such ions that were successively freed from AMPC. Different reaction systems were investigated in order to improve the enantiomeric excess and the results are shown in Table V. Optically active salithion of nearly $90 \%$ e.e. was obtained when the reaction was carried out in chloroform and when triethylamine was used to remove the hydrogen chloride produced.

The optical isomers of CMMBS were synthesized in acetone using potassium carbonate as a base. After separating the cis and trans isomers, the two cis enantiomers from $(S)$ $(+)$ - and $(R)-(-)$-CMPC respectively showed almost same optical purity of $97 \%$ e.e. on the basis of chiral column chromatography. Unfortunately, the enantiomers of the trans isomer could not be distinguished by this 


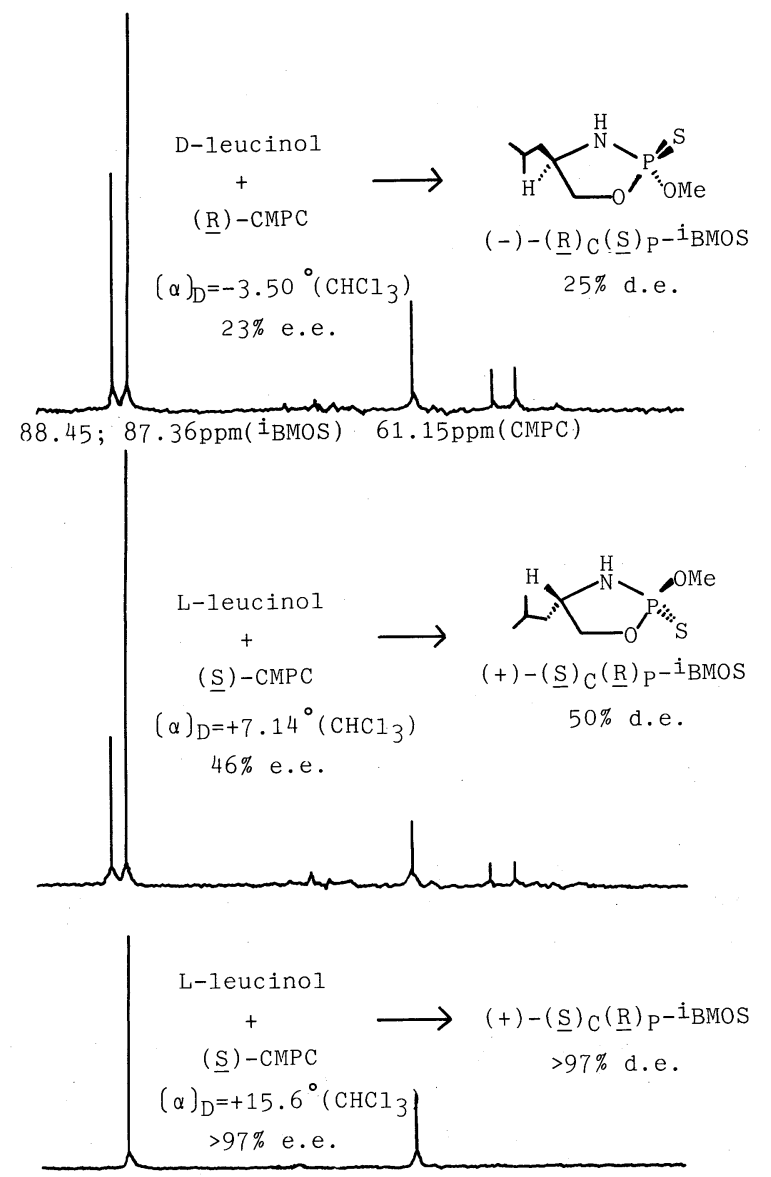

FIG. 2. ${ }^{31}$ P-NMR Monitoring of the Reaction between Chiral Leucinols and CMPC of Differing Optical Purity.

Table V. Syntheses of Optically Active Salithion under Different Conditions<smiles>[CH2-][P+](O)(=S)OC</smiles>

A<smiles>OCc1ccccc1O</smiles>

B<smiles>CC</smiles><smiles>CO[P@]1(=S)OCc2ccccc2O1</smiles>

C

\begin{tabular}{lccc}
\hline$(+)-\mathbf{A}$, e.e. $\%$ & B & Reaction conditions & C, $(+):(-)$ \\
\hline MNPC, $>97$ & Saligenin & NaOH, BTEAC, ${ }^{a} \mathrm{H}_{2} \mathrm{O} / \mathrm{CH}_{2} \mathrm{Cl}_{2}$ & $54: 46$ \\
CMPC, 95 & SHMP & acetone & $76: 24$ \\
CMPC, 95 & SHMP & 15-Crown-5(0.5), ${ }^{c}$ acetone & $80: 20$ \\
CMPC, 95 & SHMP & 15-Crown-5(0.5), $\mathrm{CHCl}_{3}$ & $86: 14$ \\
CMPC, 95 & SHMP & 18-Crown-6(0.5), $\mathrm{CHCl}_{3}$ & $72: 28$ \\
CMPC, 95 & SHMP & 15-Crown-5(0.25), $\mathrm{CHCl}_{3}$ & $81: 19$ \\
CMPC, $>97$ & SHMP & 15-Crown-5(1.0), $\mathrm{CHCl}_{3}$ & $90: 10$ \\
MNPC, $>97$ & Saligenin & $\mathrm{Et}_{3} \mathrm{~N}, \mathrm{CHCl}_{3}$ & $94: 6$ \\
\hline
\end{tabular}

a Benzyltriethylammonium chloride.

$b$ Sodium 2-hydroxymethyl phenoxide.

c Mole ratios to $1 \mathrm{~mol}$ of AMPC. 


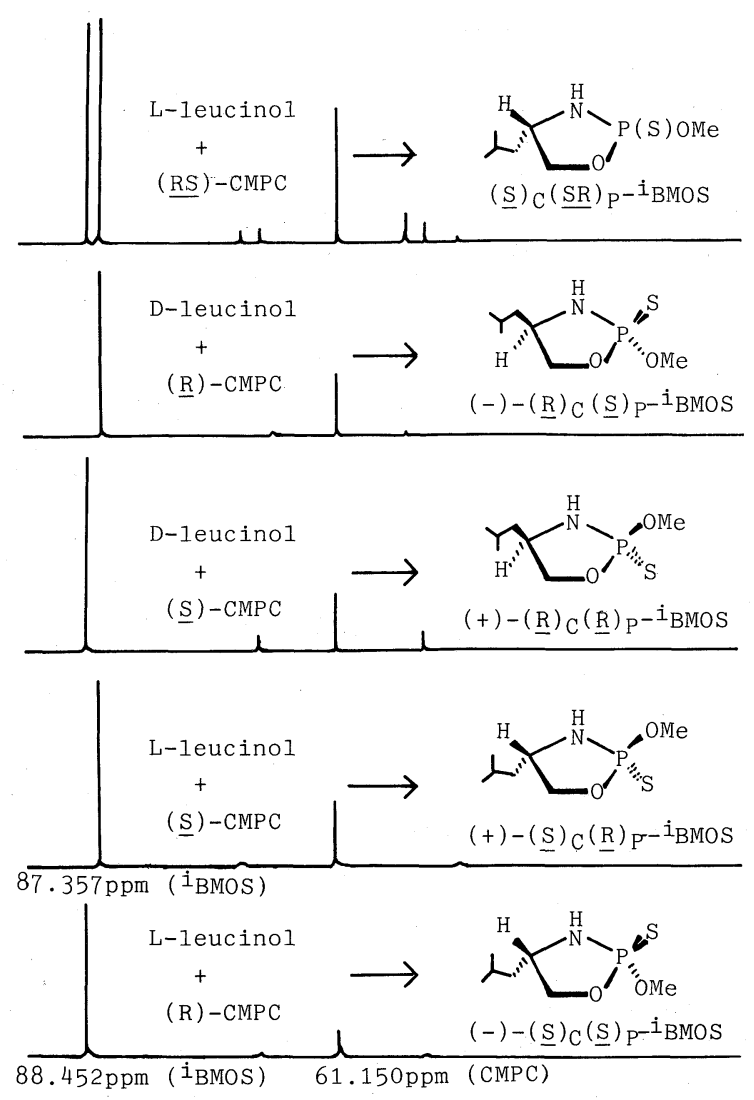

FIG. 3. ${ }^{31}$ P-NMR Monitoring of the Reaction between Pure Enantiomers of Leucinols and CMPC.

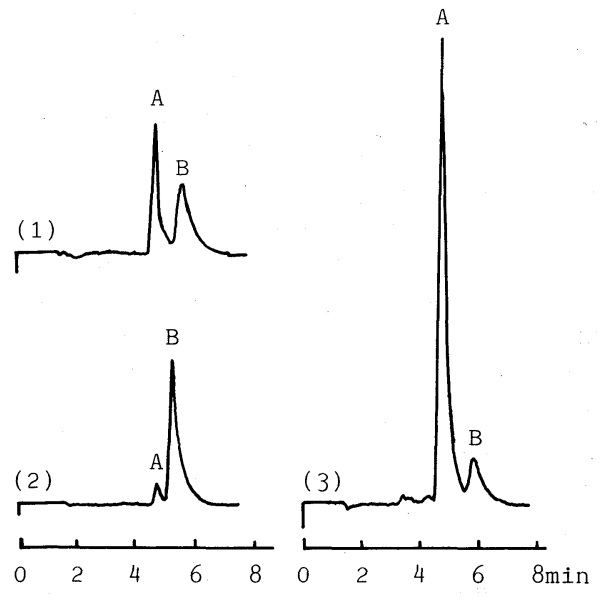

FIG. 4. HPLC Analyses of Enantiomeric Salithion.

(1), industrial product; (2), (3), optically active products. A, B $(S)-(-)$ - and $(R)-(+)$-salithion, respectively. column under various conditions using several different systems of eluants.

\section{EXPERIMENTAL}

Optically active 2-aminoalcohols. Those that were not available from commercial sources were respectively synthesized from the corresponding amino acids by Brenner's and Seki's methods for preparing amino acid methyl ester hydrochlorides ${ }^{10)}$ and their reduction with sodium borohydride. ${ }^{11)}$ The synthesis of $(R)$-2-amino-4-methyl-1pentanol(D-leucinol) is exemplified below.

(R)-2-Amino-4-methyl-1-pentanol (D-leucinol).

(a) D-Leucine methyl ester hydrochloride. To a solution of thionyl chloride $(6.64 \mathrm{~g}, 0.057 \mathrm{~mol})$ in $15 \mathrm{ml}$ of methanol was added D-leucine $(6.60 \mathrm{~g}, 0.051 \mathrm{~mol})$ at $-10^{\circ} \mathrm{C}$. The reaction mixture was stirred at $40^{\circ} \mathrm{C}$ for $3 \mathrm{hr}$, and then overnight at room temperature. After evaporating the methanol, the crystals obtained were recrystallized from methanol and ether. Yield $7.8 \mathrm{~g}, 86^{\circ} \%$; mp $144 \sim 146^{\circ} \mathrm{C}$.

(b) D-Leucinol. To a solution of sodium borohydride $(6.8 \mathrm{~g}, 0.18 \mathrm{~mol})$ in $75 \%$ ethanol $(80 \mathrm{ml})$ was added drop- 
wise a solution of D-leucine methyl ester hydrochloride $(7.8 \mathrm{~g}, 0.043 \mathrm{~mol})$ in $80 \mathrm{ml}$ of $75 \%$ ethanol at room temperature. The mixture was refluxed for $5.5 \mathrm{hr}$, the ethanol was evaporated, and the residual solution was extracted with ethyl acetate $(20 \mathrm{ml} \times 3)$. After drying and concentrating, the product was purified by distillation. Yield $4.2 \mathrm{~g}$, $83 \%$; bp $108 \sim 110^{\circ} \mathrm{C}(18 \mathrm{mmHg}) ;{ }^{1} \mathrm{H}-\mathrm{NMR} \delta \mathrm{ppm}: 0.90$, $0.94\left(6 \mathrm{H}, 2 \mathrm{~d}, J=7 \mathrm{~Hz}, \mathrm{CH}\left(\mathrm{CH}_{3}\right)_{2}\right), 1.14,1.22(2 \mathrm{H}, 2 \mathrm{~d}, J=$ $\left.7 \mathrm{~Hz},\left(\mathrm{CH}_{3}\right)_{2} \mathrm{CHCH}_{2}\right), 1.68\left(1 \mathrm{H}, \mathrm{m}, J=7 \mathrm{~Hz},\left(\mathrm{CH}_{3}\right)_{2} \mathrm{CH}\right)$, $2.2\left(3 \mathrm{H}, \mathrm{N}_{2}, \mathrm{OH}\right), 2.90\left(1 \mathrm{H}, \mathrm{m}, \mathrm{C}_{\underline{H}} \mathrm{H}_{2}\right), 3.1 \sim 3.6$ (2H, m, $\left.\mathrm{CH}_{2} \mathrm{OH}\right)$.

The following aminoalcohols were derived from the corresponding amino acids by a similar procedure to that described above.

(R)-2-Amino-3-methyl-1-butanol (D-valinol). bp $95^{\circ} \mathrm{C}$ $(22 \mathrm{mmHg}) ;{ }^{1} \mathrm{H}-\mathrm{NMR} \delta \mathrm{ppm}: 0.92(6 \mathrm{H}, \mathrm{d}, J=7 \mathrm{~Hz}$, $\left.\mathrm{CH}\left(\mathrm{CH}_{3}\right)_{2}\right), 1.56\left(1 \mathrm{H}, \mathrm{m}, J=7 \mathrm{~Hz},\left(\mathrm{CH}_{3}\right)_{2} \mathrm{CH}\right), 2.52(1 \mathrm{H}$, $\left.\mathrm{m}, \mathrm{NH}_{2} \mathrm{C} \underline{\mathrm{H}}\right), 2.6 \sim 2.8\left(3 \mathrm{H}, \mathrm{NH}_{2}, \mathrm{OH}\right), 3.2 \sim 3.7(2 \mathrm{H}, \mathrm{m}$, $\mathrm{C}_{2} \mathrm{OH}$ ).

(S)-2-Amino-2-phenylethanol (L-phenylglycinol). bp $150^{\circ} \mathrm{C}(15 \mathrm{mmHg}) ;{ }^{1} \mathrm{H}-\mathrm{NMR} \delta \mathrm{ppm}, 2.46\left(3 \mathrm{H}, \mathrm{NH}_{2}, \mathrm{OH}\right)$, $3.4 \sim 3.8\left(2 \mathrm{H}, \mathrm{m}, \mathrm{CH}_{2} \mathrm{OH}\right), 4.02(1 \mathrm{H}, \mathrm{m}, \mathrm{PhC} \underline{\mathrm{H}}), 7.28(5 \mathrm{H}$, $\left.\mathrm{s}, \mathrm{C}_{6} \underline{\mathrm{H}}_{5}\right)$.

$(R)$ - and (S)-2-Amino-3,3-dimethyl-1-butanol (D- and Ltert-leucinol $)$ bp $130^{\circ} \mathrm{C}(32 \mathrm{mmHg}) ;{ }^{1} \mathrm{H}-\mathrm{NMR} \delta$ ppm: 0.90 $\left(9 \mathrm{H}, \mathrm{s}, \mathrm{C}\left(\mathrm{C}_{3}\right)_{3}\right), 1.8\left(3 \mathrm{H}, \mathrm{NH}_{2}, \mathrm{O} \underline{\mathrm{H}}\right), 2.50(1 \mathrm{H}, \mathrm{m}$, $\left.\mathrm{CHNH}_{2}\right), 3.19\left(2 \mathrm{H}, \mathrm{m}, \mathrm{C}_{2} \mathrm{OH}\right)$.

(R)-2-Amino-1-propanol (D-alaninol). bp $82 \sim 84^{\circ} \mathrm{C}$ (25 mmHg); ${ }^{1} \mathrm{H}-\mathrm{NMR} \delta$ ppm: $1.04\left(3 \mathrm{H}, \mathrm{d}, \mathrm{CH}_{3}\right), 2.7(3 \mathrm{H}$, $\left.\mathrm{s}, \mathrm{NH}_{2}, \mathrm{OH}\right), 3.0\left(1 \mathrm{H}, \mathrm{m}, \mathrm{CHNH}_{2}\right), 3.12 \sim 3.62(2 \mathrm{H}, \mathrm{m}$, $\mathrm{CH}_{2} \mathrm{OH}$ ).

(R)-2-Amino-3-phenyl-1-propanol(D-phenylalaninol). $\mathrm{mp}$ $90 \sim 92^{\circ} \mathrm{C}$ (recrystallized from ether and methanol); ${ }^{1} \mathrm{H}$ NMR $\delta$ ppm: $2.1\left(3 \mathrm{H}, \mathrm{s}, \mathrm{N}_{2}, \mathrm{OH}\right), 2.6\left(2 \mathrm{H}, \mathrm{m}, \mathrm{PhC}_{2}\right)$, $3.1\left(1 \mathrm{H}, \mathrm{m}, \mathrm{CHNH}_{2}\right), 3.5\left(2 \mathrm{H}, \mathrm{m}, \mathrm{CH}_{2} \mathrm{OH}\right)$.

2-(1-Hydroxyethyl)-4-chlorophenol. This was synthesized from 4-chlorophenol by successive acetylation, Fries rearrangement and reduction.

(a) 4-Chlorophenyl acetate. 4-Chlorophenol (12.8 g, $0.10 \mathrm{~mol})$ and sodium acetate $(2.1 \mathrm{~g}, 0.03 \mathrm{~mol})$ were mixed in acetic anhydride $(15.0 \mathrm{~g}, 0.15 \mathrm{~mol})$ and refluxed for $1 \mathrm{hr}$, the mixture then $b$ :ng cooled to near $0^{\circ} \mathrm{C}$, washed with $80 \mathrm{ml}$ cold water, and extracted with ether $(20 \mathrm{ml} \times 3)$. The ether extracts were dried over anhydrous sodium sulfate. Distillation gave the product as a clear oil. bp $118^{\circ} \mathrm{C}$ $\left(22 \mathrm{mmHg}\right.$ ), yield $80 \%$. ${ }^{1} \mathrm{H}-\mathrm{NMR} \delta \mathrm{ppm}: 2.32(3 \mathrm{H}, \mathrm{s}$, $\left.\mathrm{COCH}_{3}\right), 7.2(4 \mathrm{H}, \mathrm{m}$, aromatic).

(b) 2-Acetyl-4-chlorophenol. Anhydrous aluminum chloride $(13 \mathrm{~g}, 0.1 \mathrm{~mol})$ was added into a three-neck flask containing $13 \mathrm{~g}$ of 4-chlorophenyl acetate, the mixture being slowly heated and stirred with a mechanical stirrer.
When the temperature approached $80^{\circ} \mathrm{C}$, the reaction became violent and much hydrogen chloride was liberated. The mixture was kept at about $160^{\circ} \mathrm{C}$ for $1 \mathrm{hr}$ and then cooled to room temperature, before dilute $\mathrm{HCl}(30 \mathrm{ml})$ cooled with ice was added to free the product. The water solution was extracted with ether $(15 \mathrm{ml} \times 3)$, and the ether layers were combined and washed with water $(10 \mathrm{ml} \times 2)$ before being dried over anhydrous sodium sulfate. The product was purified by recrystallization from methanol. mp $52 \sim 54^{\circ} \mathrm{C}$, yield $16 \mathrm{~g}, 62 \%,{ }^{1} \mathrm{H}-\mathrm{NMR} \delta \mathrm{ppm}: 2.60(3 \mathrm{H}$, $\left.\mathrm{s}, \mathrm{COCH}_{3}\right), 6.48 \sim 7.68(3 \mathrm{H}, \mathrm{m}$, aromatic $), 12.1(1 \mathrm{H}, \mathrm{s}$, $\mathrm{PhOH})$.

(c) 2-(1-Hydroxyethyl)-4-chlòrophenol. To lithium aluminum hydride $(1.5 \mathrm{~g}, 0.04 \mathrm{~mol})$ suspended in dry ether $(50 \mathrm{ml})$ was added dropwise a solution of 2-acetyl-4chlorophenol $(8.2 \mathrm{~g}, 0.048 \mathrm{~mol})$ in ether $(50 \mathrm{ml})$, before the mixture being stirred for $0.5 \mathrm{hr}$ at toom temperature then $3 \% \mathrm{HCl}$ was slowly added. The ether layer separated, washed with water $(20 \mathrm{ml} \times 2)$ and dried over anhydrous sodium sulfate. A pure product was obtained by recrystallization from benzene and hexane. mp $99 \sim 100^{\circ} \mathrm{C}$, yield $5.7 \mathrm{~g}, 69 \%$. ${ }^{1} \mathrm{H}-\mathrm{NMR} \delta \mathrm{ppm}: 1.58\left(3 \mathrm{H}, \mathrm{d}, \mathrm{CH}_{3}\right), 2.6$ $(1 \mathrm{H}, \mathrm{CHOH}), 5.00(1 \mathrm{H}, \mathrm{q}, \mathrm{CHOH}), 6.72 \sim 7.22(3 \mathrm{H}, \mathrm{m}$, aromatic), $7.92(1 \mathrm{H}, \mathrm{PhO} \underline{\mathrm{H}})$.

Optically active 1,3,2-oxazaphospholidine 2-sulfides. Every four optical isomers of these compounds were synthesized by different combinations of the corresponding D- and L-aminoalcohols, and $(R)$ - and $(S)$-CMPC (or MNPC). The optically active CMPC and MNPC were prepared as described in the previous paper. ${ }^{3)}$ For ${ }^{31} \mathrm{P}$ NMR monitoring, $\mathrm{CDCl}_{3}$ was used as a solvent. Such a preparation is exemplified below by the following synthesis.

$(R)_{\mathrm{C}}(S)_{\mathrm{P}}-4$ - Isopropyl-2-met hoxy-1,3,2oxazaphospholidine 2-sulfide $\left((R)_{\mathrm{C}}(S)_{\mathrm{P}^{-}}{ }^{\mathrm{i}} P M O S\right)$. To a $\mathrm{CDCl}_{3}$ solution $(1.0 \mathrm{ml})$ of $(R)-(-)-\mathrm{CMPC}(0.11 \mathrm{~g}$, $0.36 \mathrm{mmol})$, D-valinol $(0.075 \mathrm{~g}, 0.72 \mathrm{mmol}$, in $1.0 \mathrm{ml}$ of $\mathrm{CDCl}_{3}$ ) was added at room temperature. The reaction was monitored by ${ }^{31} \mathrm{P}-\mathrm{NMR}$ and no epimerization was detected from the beginning to end. After $10 \mathrm{hr}$, the CMPC was completely converted into $(R)_{\mathrm{C}}(S)_{\mathrm{P}_{\mathrm{P}}}$-PMOS. The reaction mixture was worked up in the usual manner, column chromatography being utilized for the purification with hexane and ether as the eluants. Yield $0.0425 \mathrm{~g}$, $61 \% \cdot[\alpha]_{\mathrm{D}}=-7.1^{\circ}\left(c=0.85, \mathrm{CHCl}_{3}\right)$.

By different combinations of $\mathrm{D}$ - and $\mathrm{L}$-valinols, and $(R)$ and $(S)$-CMPC (or MNPC), the four optical isomers of iPMOS were obtained separately. $(S)_{\mathrm{C}}(R)_{\mathrm{P}}{ }^{-}{ }^{\mathrm{P}} \mathrm{PMOS}: 56 \%$, $[\alpha]_{\mathrm{D}}+7.1^{\circ}\left(c=0.49, \mathrm{CHCl}_{3}\right) ;(S)_{\mathrm{C}}(S)_{\mathrm{P}}{ }^{\mathrm{i}} \mathrm{PMOS}: 47 \%,[\alpha]_{\mathrm{D}}$ $-27.9^{\circ}\left(c=0.20, \mathrm{CHCl}_{3}\right) ;(R)_{\mathrm{C}}(R)_{\mathrm{P}^{-}}{ }^{\mathrm{i}} \mathrm{PMOS}: 55 \%,[\alpha]_{\mathrm{D}}$ $+27.5^{\circ}\left(c=0.22, \mathrm{CHCl}_{3}\right) .{ }^{1} \mathrm{H}-\mathrm{NMR} \delta \mathrm{ppm}$ : cis isomers $\left((R)_{\mathrm{C}}(S)_{\mathrm{P}^{-}}\right.$and $\left.(S)_{\mathrm{C}}(R)_{\mathrm{P}^{-}}{ }^{\mathrm{i}} \mathrm{PMOS}\right), 0.92,0.99(6 \mathrm{H}, 2 \mathrm{~d}, J=$ $\left.7 \mathrm{~Hz}, \mathrm{CH}\left(\mathrm{CH}_{3}\right)_{2}\right), 1.72\left(1 \mathrm{H}, \mathrm{m}, \mathrm{C} \underline{\mathrm{H}}\left(\mathrm{CH}_{3}\right)_{2}\right), 3.2(1 \mathrm{H}, \mathrm{N} \underline{\mathrm{H}})$, $3.36(1 \mathrm{H}, \mathrm{m}, \mathrm{NHC} \underline{\mathrm{H}}), 3.72\left(3 \mathrm{H}, \mathrm{d}, J=15 \mathrm{~Hz}, \mathrm{POC}_{3}\right)$, $3.88 \sim 4.48\left(2 \mathrm{H}, \mathrm{m}, \mathrm{OCH}_{2}\right) ;$ trans isomers $\left((R)_{\mathrm{C}}(R)_{\mathrm{P}^{-}}\right.$and 
$\left.(S)_{\mathrm{C}}(S)_{\mathrm{P}}{ }^{-}{ }^{\mathrm{P}} \mathrm{PMOS}\right), \quad 0.86, \quad 0.94 \quad(6 \mathrm{H}, \quad 2 \mathrm{~d}, \quad J=7 \mathrm{~Hz}$, $\left.\mathrm{CH}\left(\mathrm{CH}_{3}\right)_{2}\right), 1.60\left(1 \mathrm{H}, \mathrm{m}, \mathrm{C} \underline{\mathrm{H}}\left(\mathrm{CH}_{3}\right)_{2}\right), 3.28(1 \mathrm{H}, \mathrm{N} \underline{\mathrm{H}}), 3.52$ $(1 \mathrm{H}, \mathrm{m}, \mathrm{NHCH}), 3.84 \sim 4.60\left(2 \mathrm{H}, \mathrm{m}, \mathrm{OCH}_{2}\right), 3.72(3 \mathrm{H}, \mathrm{d}$, $\left.J=15 \mathrm{~Hz}, \mathrm{POCH}_{3}\right) .{ }^{31} \mathrm{P}-\mathrm{NMR} \delta \mathrm{ppm}:$ cis isomers, 87.1; trans isomers, 88.8. Mass $m / z$ : $195\left(\mathrm{M}^{+}\right)$.

By a similar procedure, the following homologs were prepared. Yields and optical rotations are together given in Table I.

4-Isobutyl-2-methoxy-1,3,2-oxazaphospholidine 2-sulfide $\left({ }^{\mathrm{i}} B M O S\right) .{ }^{1} \mathrm{H}-\mathrm{NMR} \delta$ ppm: cis isomers $\left((R)_{\mathrm{C}}(S)_{\mathrm{P}^{-}}\right.$and $\left.(S)_{\mathrm{C}}(R)_{\mathrm{P}^{-}}{ }^{\mathrm{i}} \mathrm{BMOS}\right), \quad 0.94, \quad 0.98 \quad(6 \mathrm{H}, \quad 2 \mathrm{~d}, \quad J=7 \mathrm{~Hz}$, $\left.\mathrm{CH}\left(\mathrm{CH}_{3}\right)_{2}\right), 1.52\left(2 \mathrm{H}, \mathrm{m},\left(\mathrm{CH}_{3}\right)_{2} \mathrm{CHCH}_{2}\right), 1.64(1 \mathrm{H}, \mathrm{m}$, $\left.\left(\mathrm{CH}_{3}\right)_{2} \mathrm{CHCH}_{2}\right), 3.04(1 \mathrm{H}, \mathrm{NH}), 3.72(3 \mathrm{H}, \mathrm{d}, J=15 \mathrm{~Hz}$, $\left.\mathrm{POCH}_{3}\right), 3.80(1 \mathrm{H}, \mathrm{m}, \mathrm{NHCH}), 3.9 \sim 4.5\left(2 \mathrm{H}, \mathrm{m}, \mathrm{OC}_{2}\right)$; trans isomers $\left((R)_{\mathrm{C}}(R)_{\mathrm{P}^{-}}\right.$and $\left.(S)_{\mathrm{C}}(S)_{\mathrm{P}^{-}}{ }^{\mathrm{i}} \mathrm{BMOS}\right), 0.93,0.95$ $\left(6 \mathrm{H}, \quad 2 \mathrm{~d}, \quad J=7 \mathrm{~Hz}, \quad \mathrm{CH}\left(\mathrm{CH}_{3}\right)_{2}\right), \quad 1.40 \quad(2 \mathrm{H}, \quad \mathrm{m}$, $\left.\left(\mathrm{CH}_{3}\right)_{2} \mathrm{CHCH}_{2}\right), 1.60\left(1 \mathrm{H}, \mathrm{m},\left(\mathrm{CH}_{3}\right)_{2} \mathrm{CH}\right), 3.24(1 \mathrm{H}, \mathrm{NH})$, $3.72\left(3 \mathrm{H}, \mathrm{d}, J=15 \mathrm{~Hz}, \mathrm{POCH}_{3}\right), 3.88(1 \mathrm{H}, \mathrm{m}, \mathrm{NHCH})$, $3.8 \sim 4.6\left(2 \mathrm{H}, \mathrm{m}, \mathrm{OCH}_{2}\right) .{ }^{31} \mathrm{P}-\mathrm{NMR} \delta \mathrm{ppm}$ : cis isomers, 87.4; trans isomers, 88.5.

4-Phenyl-2-methoxy-1,3,2-oxazaphospholidine 2-sulfide (PMOS). ${ }^{1} \mathrm{H}-\mathrm{NMR} \delta \mathrm{ppm}$ : cis isomers $\left((R)_{\mathrm{C}}(S)_{\mathrm{P}^{-}}\right.$and $(S)_{\mathrm{C}}(R)_{\mathrm{P}}$-PMOS), $3.4(1 \mathrm{H}, \mathrm{NH}), 3.77(3 \mathrm{H}, \mathrm{d}, J=15 \mathrm{~Hz}$, $\left.\mathrm{POCH}_{3}\right), 3.6 \sim 5.0\left(3 \mathrm{H}, \mathrm{m}, \mathrm{NHC} \underline{\mathrm{HCH}}_{2} \mathrm{O}\right), 7.34(5 \mathrm{H}, \mathrm{s}$, $\left.\mathrm{C}_{6} \underline{\mathrm{H}}_{5}\right)$, trans isomers $\left((R)_{\mathrm{C}}(R)_{\mathrm{P}^{-}}\right.$and $\left.(S)_{\mathrm{C}}(S)_{\mathrm{P}}-\mathrm{PMOS}\right), 3.5$ $(1 \mathrm{H}, \mathrm{NH}), 3.81\left(3 \mathrm{H}, \mathrm{d}, J=15 \mathrm{~Hz}, \mathrm{POC}_{\underline{H}_{3}}\right), 3.6 \sim 5.0(3 \mathrm{H}$, m, NHC $\left.\underline{H C}_{2} \mathrm{O}\right), 7.34\left(5 \mathrm{H}, \mathrm{s}, \mathrm{C}_{6} \underline{\mathrm{H}}_{5}\right) .{ }^{31} \mathrm{P}-\mathrm{NMR} \delta \mathrm{ppm}$ : cis isomers, 86.0; trans isomers, 88.0.

2-tert-Butyl-2-methoxy-1,3,2-oxazaphospholidine 2-sulfide $\left({ }^{\mathrm{t}} B M O S\right) .{ }^{1} \mathrm{H}-\mathrm{NMR} \delta \mathrm{ppm}$ : cis isomer $\left((R)_{\mathrm{C}}(S)_{\mathrm{P}^{-}}\right.$and $\left.(S)_{\mathrm{C}}(R)_{\mathrm{p}^{-}}{ }^{-} \mathrm{BMOS}\right), 0.94\left(9 \mathrm{H}, \mathrm{s}, \mathrm{C}\left(\mathrm{C}_{3}\right)_{3}\right), 3.14(1 \mathrm{H}, \mathrm{N} \underline{\mathrm{H}})$, $3.4(1 \mathrm{H}, \mathrm{m}, \mathrm{NHCH}), 3.71\left(3 \mathrm{H}, \mathrm{d}, \mathrm{POCH}_{3}\right), 4.2(2 \mathrm{H}, \mathrm{m}$, $\left.\mathrm{CH}_{2} \mathrm{O}\right)$; trans isomers $\left((S)_{\mathrm{C}}(S)_{\mathrm{P}^{-}}\right.$and $\left.(R)_{\mathrm{C}}(R)_{\mathrm{P}^{-}}{ }^{\mathrm{t}} \mathrm{BMOS}\right)$, $0.88\left(9 \mathrm{H}, \mathrm{s}, \mathrm{C}\left(\mathrm{C}_{3}\right)_{3}\right), 3.18(1 \mathrm{H}, \mathrm{N} \underline{\mathrm{H}}), 3.6(1 \mathrm{H}, \mathrm{m}, \mathrm{N} \underline{\mathrm{HC}})$, $3.71\left(3 \mathrm{H}, \mathrm{d}, \mathrm{POCH}_{3}\right), 4.2\left(2 \mathrm{H}, \mathrm{m}, \mathrm{CH}_{2} \mathrm{O}\right) .{ }^{31} \mathrm{P}-\mathrm{NMR}$ $\delta$ ppm: cis isomers, 86.8 ; trans isomers, 89.4.

4-Ethyl-2-methoxy-1,3,2-oxazaphospholidine 2-sulfide $(E M O S) .{ }^{1} \mathrm{H}-\mathrm{NMR} \delta \mathrm{ppm}$ : cis isomers $\left((R)_{\mathrm{C}}(S)_{\mathrm{P}^{-}}\right.$and $(S)_{\mathrm{C}}(R)_{\mathrm{P}}$-EMOS), $0.96\left(3 \mathrm{H}, \mathrm{t}, \mathrm{CH}_{2} \mathrm{CH}_{3}\right), 1.62(2 \mathrm{H}, \mathrm{m}$, $\left.\mathrm{CH}_{3} \mathrm{CH}_{2}\right), 3.14(1 \mathrm{H}, \mathrm{NH}), 3.6(1 \mathrm{H}, \mathrm{m}, \mathrm{CHNH}), 3.71(3 \mathrm{H}$, $\left.\mathrm{d}, J=15 \mathrm{~Hz}, \mathrm{POCH}_{3}\right), 4.0,4.4\left(2 \mathrm{H}, \mathrm{m}, \mathrm{CH}_{2} \mathrm{O}\right)$, trans isomers $\left((S)_{\mathrm{C}}(S)_{\mathrm{P}^{-}}\right.$and $\left.(R)_{\mathrm{C}}(R)_{\mathrm{P}^{-}} \mathrm{EMOS}\right), 0.94(3 \mathrm{H}, \mathrm{t}$, $\left.\mathrm{CH}_{2} \mathrm{CH}_{3}\right), 1.56\left(2 \mathrm{H}, \mathrm{m}, \mathrm{CH}_{2} \mathrm{CH}_{3}\right), 3.3(1 \mathrm{H}, \mathrm{N} \underline{\mathrm{H}}), 3.7(1 \mathrm{H}$, $\mathrm{m}, \mathrm{C} \underline{\mathrm{HNH}}), 3.71\left(3 \mathrm{H}, \mathrm{d}, J=15 \mathrm{~Hz}, \mathrm{POCH}_{3}\right), 3.9,4.4(2 \mathrm{H}$, $\left.\mathrm{m}, \mathrm{CH}_{2} \mathrm{O}\right) .{ }^{31} \mathrm{P}-\mathrm{NMR} \delta \mathrm{ppm}$ : cis isomers, 87.0; trans isomers, 88.6.

4-Benzyl-2-methoxy-1,3,2-oxazaphospholidine 2-sulfide $(B M O S) .{ }^{1} \mathrm{H}-\mathrm{NMR} \delta$ ppm: cis isomers $\left((R)_{\mathrm{C}}(S)_{\mathrm{P}^{-}}\right.$and $(S)_{\mathrm{C}}(R)_{\mathrm{P}}$-BMOS), $2.88\left(2 \mathrm{H}, \mathrm{d}, \mathrm{PhCH}_{2}\right), 3.68(3 \mathrm{H}, \mathrm{d}, J=$ $\left.15 \mathrm{~Hz}, \mathrm{POCH}_{3}\right), 3.8(1 \mathrm{H}, \mathrm{m}, \mathrm{C} \underline{\mathrm{HNH}}), 4.08,4.30(2 \mathrm{H}, \mathrm{m}$, $\left.\mathrm{CH}_{2} \mathrm{O}\right), 7.24\left(5 \mathrm{H}\right.$, aromatic); trans isomers $\left((S)_{\mathrm{C}}(S)_{\mathrm{P}^{-}}\right.$and $\left.(R)_{\mathrm{C}}(R)_{\mathrm{P}}-\mathrm{BMOS}\right), 2.78\left(2 \mathrm{H}, \mathrm{d}, \mathrm{PhC}_{2}\right), 3.28(1 \mathrm{H}, \mathrm{N} \underline{\mathrm{H}})$, $3.75\left(3 \mathrm{H}, \mathrm{d}, J=15 \mathrm{~Hz}, \mathrm{POCH}_{3}\right), 4.0(1 \mathrm{H}, \mathrm{m}, \mathrm{CHNH}), 4.0$, $4.4\left(2 \mathrm{H}, \mathrm{m}, \mathrm{CH}_{2} \mathrm{O}\right), 7.20$ (5H, aromatic). ${ }^{31} \mathrm{P}-\mathrm{NMR} \delta \mathrm{ppm}$ : cis isomers, 85.6; trans isomers, 87.8.

4-Methyl-2-methoxy-1,3,2-oxazaphospholidine 2-sulfide $(M M O S) .{ }^{1} \mathrm{H}-\mathrm{NMR} \delta \mathrm{ppm}: c i s$ isomers $\left((R)_{\mathrm{C}}(S)_{\mathrm{P}^{-}}\right.$and $\left.(S)_{\mathrm{C}}(R)_{\mathrm{P}}-\mathrm{MMOS}\right), 1.31\left(3 \mathrm{H}, \mathrm{d}, \mathrm{CHCH}_{3}\right), 3.04(1 \mathrm{H}, \mathrm{NH})$, $3.73\left(3 \mathrm{H}, \mathrm{d}, J=15 \mathrm{~Hz}, \mathrm{POCH}_{3}\right), 3.8(1 \mathrm{H}, \mathrm{m}, \mathrm{CHNH}), 3.9$, $4.36\left(2 \mathrm{H}, \quad \mathrm{m}, \mathrm{CH}_{2} \mathrm{O}\right)$; trans isomers $\left((S)_{\mathrm{C}}(S)_{\mathrm{P}^{-}}\right.$and $\left.(R)_{\mathrm{C}}(R)_{\mathrm{P}}-\mathrm{MMOS}\right), 1.24\left(3 \mathrm{H}, \mathrm{d}, \mathrm{CHCH}_{3}\right), 3.2(1 \mathrm{H}, \mathrm{N} \underline{\mathrm{H}})$, $3.71\left(3 \mathrm{H}, \mathrm{d}, J=15 \mathrm{~Hz}, \mathrm{POCH}_{3}\right), 3.8,4.4\left(2 \mathrm{H}, \mathrm{m}, \mathrm{CH}_{2} \mathrm{O}\right)$. ${ }^{31} \mathrm{P}-\mathrm{NMR} \delta \mathrm{ppm}$ : cis isomers, 86.9; trans isomers, 88.2.

5-Methyl-2-methoxy-1,3,2-oxazaphospholidine 2-sulfide $\left(M^{\prime} M O S\right) .{ }^{1} \mathrm{H}-\mathrm{NMR} \delta \mathrm{ppm}: c i s$ isomers $\left((R)_{\mathrm{C}}(R)_{\mathrm{P}^{-}}\right.$and $\left.(S)_{\mathrm{C}}(S)_{\mathrm{P}}-\mathrm{M}^{\prime} \mathrm{MOS}\right), 1.46\left(3 \mathrm{H}, \mathrm{d}, \mathrm{CHCH}_{3}\right), 3.0 \sim 3.6(3 \mathrm{H}$, $\left.\mathrm{m}, \mathrm{CH}_{2} \mathrm{NH}\right), 3.72\left(3 \mathrm{H}, \mathrm{d}, J=15 \mathrm{~Hz}, \mathrm{POCH}_{3}\right), 4.66(1 \mathrm{H}, \mathrm{m}$, OCH $)$; trans isomers $\left((R)_{\mathrm{C}}(S)_{\mathrm{P}^{-}}\right.$and $\left.(S)_{\mathrm{C}}(R)_{\mathrm{P}^{-}}-\mathrm{M}^{\prime} \mathrm{MOS}\right)$, $1.43\left(3 \mathrm{H}, \mathrm{d}, \mathrm{CHCH}_{3}\right), 2.8 \sim 3.6\left(3 \mathrm{H}, \mathrm{m}, \mathrm{CH}_{2} \mathrm{NH}\right), 3.72$ $\left(3 \mathrm{H}, \mathrm{d}, J=15 \mathrm{~Hz}, \mathrm{POCH}_{3}\right), 4.68(1 \mathrm{H}, \mathrm{m}, \mathrm{OC} \underline{\mathrm{H}}) .{ }^{31} \mathrm{P}-\mathrm{NMR}$ $\delta$ ppm: cis isomers, 87.0; trans isomers, 87.8.

4-sec-Butyl-2-methoxy-1,3,2-oxazaphospholidine 2-sulfide $\left({ }^{\mathrm{s}} B M O S\right) .{ }^{1} \mathrm{H}-\mathrm{NMR} \delta \mathrm{ppm}$ : cis isomer $\left((S)_{\mathrm{C}}(S)_{\mathrm{C}}(R)_{\mathrm{P}^{-}}\right.$ $\left.{ }^{\mathrm{s}} \mathrm{BMOS}\right), 0.90\left(3 \mathrm{H}, \mathrm{d}, \mathrm{CHCH}_{3}\right), 0.93\left(3 \mathrm{H}, \mathrm{t}, \mathrm{CH}_{2} \mathrm{CH}_{3}\right)$, $1.0 \sim 1.7\left(3 \mathrm{H}, \mathrm{m}, \mathrm{CHCH}_{2}\right), 3.16(1 \mathrm{H}, \mathrm{N} \underline{\mathrm{H}}), 3.48(1 \mathrm{H}, \mathrm{m}$, $\mathrm{CHNH}), 3.71\left(3 \mathrm{H}, \mathrm{d}, J=15 \mathrm{~Hz}, \mathrm{POCH}_{3}\right), 3: 9 \sim 4.5(2 \mathrm{H}, \mathrm{m}$, $\left.\mathrm{CH}_{2} \mathrm{O}\right)$; trans isomer $\left((S)_{\mathrm{C}}(S)_{\mathrm{C}}(S)_{\mathrm{P}^{-}}{ }^{\mathrm{s}} \mathrm{BMOS}\right), 0.82(3 \mathrm{H}, \mathrm{d}$, $\left.\mathrm{CHCH}_{3}\right), 0.90\left(3 \mathrm{H}, \mathrm{t}, \mathrm{CH}_{2} \mathrm{CH}_{3}\right), 1.0 \sim 1.7(3 \mathrm{H}, \mathrm{m}$, $\left.\mathrm{C}^{\mathrm{HCH}} \underline{\mathrm{H}}_{2}\right), 3.30(1 \mathrm{H}, \mathrm{N} \underline{\mathrm{H}}), 3.56(1 \mathrm{H}, \mathrm{m}, \mathrm{C} \underline{\mathrm{HNH}}), 3.71(3 \mathrm{H}$, $\left.\mathrm{d}, J=15 \mathrm{~Hz}, \mathrm{POCH}_{3}\right), 3.96,4.34\left(2 \mathrm{H}, \mathrm{m}, \mathrm{CH}_{2} \mathrm{O}\right) .{ }^{31} \mathrm{P}-$ NMR $\delta$ ppm: cis isomer, 87.3; trans isomer, 88.9.

2-Methoxy-1,3,2-oxazaphospholidine 2-sulfide (MOS). ${ }^{1} \mathrm{H}-\mathrm{NMR} \delta$ ppm: $3.2(1 \mathrm{H}, \mathrm{NH}), 3.44\left(2 \mathrm{H}, \mathrm{m}, \mathrm{CH}_{2} \mathrm{NH}\right)$, $3.74\left(3 \mathrm{H}, \mathrm{d}, J=15 \mathrm{~Hz}, \mathrm{POCH}_{3}\right), 4.34\left(2 \mathrm{H}, \mathrm{m}, \mathrm{CH}_{2} \mathrm{O}\right) .{ }^{31} \mathrm{P}-$ NMR $\delta$ ppm: 88.4 .

5-Ethyl-2-methoxy-1,3,2-oxazaphospholidine 2-sulfide $\left(E^{\prime} M O S\right)$. This compound was prepared from racemic starting materials and, therefore, consisted of four stereoisomers. Yield $50 \%,{ }^{1} \mathrm{H}-\mathrm{NMR} \delta \mathrm{ppm}: 1.02(3 \mathrm{H}, \mathrm{t}$, $\left.\mathrm{CH}_{2} \mathrm{CH}_{3}\right), 1.72\left(2 \mathrm{H}, \mathrm{m}, \mathrm{CH}_{3} \mathrm{CH}_{2}\right), 2.9 \sim 3.6(3 \mathrm{H}, \mathrm{m}$, $\left.\mathrm{C}_{2}{ }_{2} \mathrm{~N}\right), 3.72\left(3 \mathrm{H}, \mathrm{d}, J=15 \mathrm{~Hz}, \mathrm{POCH}_{3}\right), 4.5(1 \mathrm{H}, \mathrm{m}$, OCH). ${ }^{31} \mathrm{P}-\mathrm{NMR} \delta \mathrm{ppm}$ : cis isomers, 87.1 ; trans isomers, 87.7.

Optically active 1,3,2-benzodioxaphosphorin 2-sulfides. Optically acțive salithion was synthesized by combinations of saligenin and chiral AMPC, the optical purity of the products from different reaction conditions varying greatly. Utilizing the reaction of racemic 2-(1-hydroxyethyl)-4chlorophenol and chiral CMPC, and following by a chromatographic separation of the diastereomers, the four optical isomers of CMMBS were prepared.

2-Methoxy-4H-1,3,2-benzodioxaphosphorin 2-sulfide 
(salithion).

(a) In an $\mathrm{NaOH}$ solution. To a $10 \% \mathrm{NaOH}$ aqueous solution $(10 \mathrm{ml})$ containing $0.093 \mathrm{~g}(0.75 \mathrm{mmol})$ of saligenin, was added dropwise a solution of $(S)-(+)$-MNPC $(0.2 \mathrm{~g}, 0.75 \mathrm{mmol})$ in $10 \mathrm{ml}$ of dichloromethane and a catalytic amount of benzyltriethylammonium chloride (BTEAC). The reaction mixture was stirred at room temperature for $1 \mathrm{hr}$, and the dichloromethane layer was separated and washed with saturated sodium chloride solution before being dried over anhydrous sodium sulfate. After filtration and concentration, the residue was purified by flash column chromatography (hexane as the eluant) to give $(R)-(+)$-salithion $(0.05 \mathrm{~g}, 34 \%, 8 \%$ e.e. $)$ and a by-product $O, O^{\prime}$-dimethyl- $O, O^{\prime}$-bis(4-nitrophenyl) dithiopyrophosphate $(0.12 \mathrm{~g})$.

(b) In chloroform using a sodium salt of saligenin and various crown ether. General procedure: To a chloroform solution $(1 \mathrm{ml})$ of sodium 2-hydroxymethylphenoxide (SHMP, $0.05 \mathrm{~g}$, prepared from saligenin and sodium hydride) containing a crown ether (about $0.04 \mathrm{~g}$ ) was added a solution of $(S)-(+)-C M P C$ (equivalent, $95 \%$ e.e.) in $1 \mathrm{ml}$ of chloroform. After stirring the mixture for $3 \mathrm{hr}$ at room temperature under anhydrous conditions, it was worked up in the usual manner. 12-Crown-4 did not give the product; dicyclohexyl 18-crown-6 gave the product, but accompanied by many by-product; from 15-crown-5 and 18-crown-6, relatively good results were obtained, but 15 crown-5 gave salithion $(68 \%$ e.e. $)$ with a higher enantiomeric excess than 18-crown-6 (optical purity of salithion was $45 \%$ e.e.).

(c) In various solvents using SHMP and 15-crown-5. By a similar procedure, the reaction was carried out separately in acetonitrile, dichloromethane, chloroform and acetone, the optical purities of salithion obtained being $22 \%, 26 \%$, $28 \%$ and $23 \%$, respectively, from the same sample of $(S)$ (+)-CMPC $(50 \%$ e.e. $)$.

(d) In acetone with and without 15-crown-5. Using (S)(+)-CMPC $(95 \%$ e.e.) and SHMP, the reaction was separately conducted in acetone with and without 15crown-5. The salithion from the crown ether had a higher optical purity $(60 \%$ e.e.) than that from the mixture without it $(53 \%$ e.e. $)$.

(e) In chloroform with different amounts of 15-crown-5. The reaction in chloroform with different amounts of 15crown-5 $(0.02 \mathrm{~g}$ and $0.05 \mathrm{~g}$; otherwise similar to (b)) also gave salithion having different optical purities (e.e.: $61 \%$ and $71 \%$, respectively).

(f) In chloroform using triethylamine as a base. To $5 \mathrm{ml}$ of chloroform containing $0.093 \mathrm{~g}(0.75 \mathrm{mmol})$ of saligenin and $0.15 \mathrm{~g}(1.5 \mathrm{mmol})$ of triethylamine was added dropwise a solution of $(S)-(+)$-MNPC $(0.2 \mathrm{~g}, 0.75 \mathrm{mmol})$ in $5 \mathrm{ml}$ of chloroform. After stirring for $4 \mathrm{hr}$ at room temperature, the mixture was worked up and purified by column chromatography (hexane used as the eluant), yield $0.04 \mathrm{~g}$, $24 \%$; optical purity, $88 \%$ e.e.

Optically active salithion used for bioassay purposes was prepared under the appropriate conditions already described. Thus, to a solution of optically pure $(S)-(+)-$ CMPC $(0.1 \mathrm{~g}, 0.33 \mathrm{mmol})$ in $5 \mathrm{ml}$ of chloroform containing 15-crown-5 $(0.073 \mathrm{~g}, 0.33 \mathrm{mmol})$ was added an equivalent of SHMP. The reaction was continued with stirring for $4 \mathrm{hr}$ under anhydrous conditions, before the mixture was washed twice with $\mathrm{H}_{2} \mathrm{O}(5 \mathrm{ml})$ and dried over anhydrous sodium sulfate. Purification with flash column chromatography using hexane as an eluant gave $(R)-(+)$-salithion, yield $0.02 \mathrm{~g}, 29 \%$. $[\alpha]_{\mathrm{D}}+7.0^{\circ}\left(c=0.40, \mathrm{CH}_{3} \mathrm{CN}\right), 79 \%$ e.e. From $(R)-(-)$-CMPC, $(S)-(-)$-salithion was obtained in a $23 \%$ yield, $[\alpha]_{\mathrm{D}}-7.8^{\circ}\left(c=0.32, \mathrm{CH}_{3} \mathrm{CN}\right), 84 \%$ e.e. ${ }^{1} \mathrm{H}$ NMR $\delta$ ppm: $3.86\left(3 \mathrm{H}, \mathrm{d}, J=14 \mathrm{~Hz}, \mathrm{POC}_{3}\right), 5.30 \sim 5.31$ $\left(2 \mathrm{H}, 2 \mathrm{~d}, J=12,14 \mathrm{~Hz}, \mathrm{C}_{2} \mathrm{OP}\right), 6.9 \sim 7.4(4 \mathrm{H}$, aromatic). ${ }^{31} \mathrm{P}-\mathrm{NMR} \delta \mathrm{ppm}:$ 59.9. Mass $m / z: 216\left(\mathrm{M}^{+}\right)$.

6-Chloro-4-methyl-2-methoxy-1,3,2-benzodioxaphosphorin 2-sulfide (CMMBS). 2-(1-Hydroxyethyl)4-chlorophenol $(0.17 \mathrm{~g}, 1.0 \mathrm{mmol})$ and ground $\mathrm{K}_{2} \mathrm{CO}_{3}$ $(0.28 \mathrm{~g}, 2.0 \mathrm{mmol})$ were mixed in $10 \mathrm{ml}$ of acetone before chiral CMPC $(0.3 \mathrm{~g}, 1.0 \mathrm{mmol})$ in $5 \mathrm{ml}$ of acetone was added. After stirring vigorously at room temperature for $4 \mathrm{hr}$, the mixture was filtered and purified by column chromatography (hexane and ether used as the eluant). Two diastereomers from each preparation were completely separated by flash column chromatography under the following conditions: column, prepacked Lobar (size B (310-25), LiChroprep Si $60(40 \sim 63 \mu \mathrm{m})$ ); eluant, an $85: 15$ mixture of hexane and ether; flow rate, about $10 \mathrm{ml} / \mathrm{min}$, controlled by an LAB pump; wavelength of the UV detector, $254 \mathrm{~nm}$.

From $(S)-(+)-C M P C$, cis $(R)_{\mathrm{C}}(R)_{\mathrm{P}}$-CMMBS $\left(15 \%,[\alpha]_{\mathrm{D}}\right.$ $+24.6^{\circ}\left(c=0.41, \mathrm{CH}_{3} \mathrm{CN}\right), 97 \%$ e.e. $)$ and trans $(S)_{\mathrm{C}}(R)_{\mathrm{P}^{-}}$ CMMBS $\left(11 \%,[\alpha]_{\mathrm{D}}-19.2^{\circ}\left(c=0.26, \mathrm{CH}_{3} \mathrm{CN}\right)\right)$; from $(R)$ $(-)$-CMPC, cis $(S)_{\mathrm{C}}(S)_{\mathrm{P}}-\mathrm{CMMBS}\left(19 \%,[\alpha]_{\mathrm{D}}-25.0^{\circ}(c=\right.$ $\left.0.48, \mathrm{CH}_{3} \mathrm{CN}\right), 97 \%$ e.e.) and trans $(R)_{\mathrm{C}}(S)_{\mathrm{P}}-\mathrm{CMMBS}$ $\left(22 \%,[\alpha]_{\mathrm{D}}+19.4^{\circ}\left(c=0.57, \mathrm{CH}_{3} \mathrm{CN}\right)\right)$ were obtained, respectively. ${ }^{1} \mathrm{H}$-NMR $\delta$ ppm: cis isomers $\left((R)_{\mathrm{C}}(R)_{\mathrm{P}^{-}}\right.$and $(S)_{\mathrm{C}}(S)_{\mathrm{P}}$-CMMBS $), 1.75,1.77\left(3 \mathrm{H}, 2 \mathrm{~d}, J=7 \mathrm{~Hz}, \mathrm{CHC}_{3}\right)$, $3.84\left(3 \mathrm{H}, \mathrm{d}, J=15 \mathrm{~Hz}, \mathrm{POC}_{3}\right), 5.52(1 \mathrm{H}, 2 \mathrm{q}, J=7 \mathrm{~Hz}$, $\left.\mathrm{CH}_{3} \mathrm{CH}\right), 6.84 \sim 7.32(3 \mathrm{H}, \mathrm{m}$, aromatic); trans isomers $\left((R)_{\mathrm{C}}(S)_{\mathrm{P}^{-}}\right.$and $\left.(S)_{\mathrm{C}}(R)_{\mathrm{P}}-\mathrm{CMMBS}\right), 1.74,1.75(3 \mathrm{H}, 2 \mathrm{~d}, J=$ $\left.7 \mathrm{~Hz}, \mathrm{CHCH}_{3}\right), 3.85\left(3 \mathrm{H}, \mathrm{d}, J=15 \mathrm{~Hz}, \mathrm{POCH}_{3}\right), 5.56,5.66$ (1H, 2q, $\left.J=7 \mathrm{~Hz}, \mathrm{CH}_{3} \mathrm{CH}\right), 6.84 \sim 7.32$ (3H, m, aromatic). ${ }^{31} \mathrm{P}-\mathrm{NMR} \delta \mathrm{ppm}$ : cis isomers, 58.9; trans isomers, 60.6. Mass $m / z: 264\left(\mathrm{M}^{+}\right)$.

Other methods. General column chromatography was performed on Merck silica gel 60 of particle size $0.063 \sim 0.2 \mathrm{~mm}$. Flash column chromatography was performed on Merck silica gel 60 of particle size $0.040 \sim 0.063 \mathrm{~mm}$. Lober prepacked columns were from Merck in size A (240-10) and size B (310-25), and were used with LiChroprep Si $60(40 \sim 63 \mu \mathrm{m})$. For the determination of optical purities, a Shimadzu LC-5A highperformance liquid chromatograph was fitted with an SPD1 UV detector (Shimadzu) and a CHROMATOPAC CR1A data processing unit (Shimadzu). The fol- 
lowing conditions were employed: column, CHIRALPAK OT(+) (from Japan Spectroscopic Co., Ltd., prepacked with chiral poly(triphenylmethylmethacrylate), $4.6 \times 250 \mathrm{~mm}$ ); mobile phase, methanol; flow rate, $1 \mathrm{ml} /$ min; pressure, $100 \mathrm{~kg} / \mathrm{cm}^{2}$; wavelength of UV detector, $254 \mathrm{~nm}$; chart speed, $5 \mathrm{~mm} / \mathrm{min}$; at room temperature.

Optical rotations were measured with a HitachiUnion Giken PM-101 polarimeter using the indicated solvents at room temperature. Mass spectra were obtained with an ESCO EMD-05A mass spectrometer at $70 \mathrm{eV} .{ }^{1} \mathrm{H}$ and ${ }^{31} \mathrm{P}-\mathrm{NMR}$ were measured with a JEOL JNM-FX 100 spectrometer at $100 \mathrm{MHz}$ and $40 \mathrm{MHz}$, respectively, using $\mathrm{CDCl}_{3}$ as a solvent, tetramethylsilane as an internal standard for ${ }^{1} \mathrm{H}-\mathrm{NMR}$, and $85 \%$ phosphoric acid as an external standard for ${ }^{31} \mathrm{P}-\mathrm{NMR}$ measurements.

Acknowledgment. This work was supported in part by a research grant from Ministry of the Agriculture, Forestry and Fishery of Japan.

\section{REFERENCES}

1) M. Eto, J. Environ. Sci. Health, B18(1), 119 (1983).

2) M. Eto, Rev. Plant Protec. Res., 9, 1 (1976).

3) S.-Y. Wu and M. Eto, Agric. Biol. Chem., 48, 3071 (1984).

4) A. Hirashima and M. Eto, Agric. Biol. Chem., 47, 2831 (1983).

5) C. R. Hall and T. D. Inch, Tetrahedron, 36, 2059 (1980).

6) L. D. Quin, "The Heterocyclic Chemistry of Phosphorus," Wiley-Interscience, New York, 1981, p. 350 .

7) D. Z. Denney, G. Y. Chen and D. B. Denney, J. Am. Chem. Soc., 91, 6838 (1969).

8) M. Revel, J. Roussel, J. Navech and F. Mathis, Org. Magnetic Resonance, 8, 399 (1976).

9) C. L. Bodkin and P. Simpson, J. Chem. Soc. (B), 1971, 1136.

10) M. Brenner and W. Huber, Helv., 36, 1109 (1953).

11) H. Seki, K. Koga, H. Matsuo, S. Ohki, I. Matsuo and S. Yamada, Chem. Pharm. Bull., 13, 995 (1965). 